\title{
Article \\ Sevoflurane and Desflurane Exposure Enhanced Cell Proliferation and Migration in Ovarian Cancer Cells via miR-210 and miR-138 Downregulation
}

\author{
Masashi Ishikawa ${ }^{1,2} \oplus$, Masae Iwasaki ${ }^{1,2}$, Hailin Zhao ${ }^{2}$, Junichi Saito ${ }^{2,3}$, Cong Hu ${ }^{2} \oplus$, Qizhe Sun ${ }^{2}$, \\ Atsuhiro Sakamoto ${ }^{1}$ and Daqing $\mathrm{Ma}^{2, *}$ \\ 1 Department of Anesthesiology and Pain Medicine, Graduate School of Medicine, Nippon Medical School, \\ Tokyo 113-8603, Japan; masashi-i@nms.ac.jp (M.I.); masae-a@nms.ac.jp (M.I.); no1-saka@nms.ac.jp (A.S.) \\ 2 Division of Anaesthetics, Pain Medicine and Intensive Care, Department of Surgery and Cancer, \\ Faculty of Medicine, Imperial College London, Chelsea \& Westminster Hospital, London SW10 9NH, UK; \\ hailin.zhao06@imperial.ac.uk (H.Z.); saitoj@hirosaki-u.ac.jp (J.S.); c.hu15@imperial.ac.uk (C.H.); \\ q.sun17@imperial.ac.uk (Q.S.) \\ 3 Department of Anesthesiology, Graduate School of Medicine, Hirosaki University, Hirosaki, \\ Aomori 036-8562, Japan \\ * Correspondence: d.ma@imperial.ac.uk
}

check for updates

Citation: Ishikawa, M.; Iwasaki, M.; Zhao, H.; Saito, J.; Hu, C.; Sun, Q.; Sakamoto, A.; Ma, D. Sevoflurane and Desflurane Exposure Enhanced Cell Proliferation and Migration in Ovarian Cancer Cells via miR-210 and miR-138 Downregulation. Int. J. Mol. Sci. 2021, 22, 1826. https:// doi.org/10.3390/ijms22041826

Academic Editor: Luba Hunáková

Received: 22 January 2021

Accepted: 8 February 2021

Published: 12 February 2021

Publisher's Note: MDPI stays neutral with regard to jurisdictional claims in published maps and institutional affiliations.

Copyright: (c) 2021 by the authors. Licensee MDPI, Basel, Switzerland. This article is an open access article distributed under the terms and conditions of the Creative Commons Attribution (CC BY) license (https:// creativecommons.org/licenses/by/ $4.0 /)$

\begin{abstract}
Inhalational anaesthetics were previously reported to promote ovarian cancer malignancy, but underlying mechanisms remain unclear. The present study aims to investigate the role of sevoflurane- or desflurane-induced microRNA (miRNA) changes on ovarian cancer cell behaviour. The cultured SKOV3 cells were exposed to $3.6 \%$ sevoflurane or $10.3 \%$ desflurane for $2 \mathrm{~h}$. Expression of miR-138, -210 and -335 was determined with qRT-PCR. Cell proliferation and migration were assessed with wound healing assay, Ki67 staining and Cell Counting Kit-8 (CCK8) assay with or without mimic miR-138/-210 transfections. The miRNA downstream effector, hypoxia inducible factor- $1 \alpha$ (HIF-1 $\alpha$ ), was also analysed with immunofluorescent staining. Sevoflurane or desflurane exposure to cancer cells enhanced their proliferation and migration. miR-138 expression was suppressed by both sevoflurane and desflurane, while miR-210 expression was suppressed only by sevoflurane. miR-335 expression was not changed by either sevoflurane or desflurane exposure. The administration of mimic miR-138 or -210 reduced the promoting effects of sevoflurane and desflurane on cancer cell proliferation and migration, in line with the HIF-1 $\alpha$ expression changes. These data indicated that inhalational agents sevoflurane and desflurane enhanced ovarian cancer cell malignancy via miRNA deactivation and HIF- $1 \alpha$. The translational value of this work needs further study.
\end{abstract}

Keywords: microRNA; sevoflurane; desflurane; hypoxia inducible factor- $1 \alpha$; ovarian cancer

\section{Introduction}

Ovarian cancer is the eighth most common cancer among women patients with poor prognosis [1,2]. The 10 year progression-free survival of ovarian cancer remains at $15 \%$, although surgery and related treatment have improved [3]. Epithelial ovarian cancer consists of $90 \%$ of ovarian cancer cases [4]. Surgical removal of cancer mass is the firstline therapy for the solid primary cancer including ovarian cancer. Postoperative cancer reoccurrence is one of the key factors leading to poor survival [5], which has been reported to be related to many risk factors including surgical trauma/stress [6] and anaesthetic use [7]. Clinical data suggested that inhalational anaesthetics may affect cancer progression and worsen long-term outcomes in patients with cancer surgery [8-11]. Our previous study showed that sevoflurane and desflurane exposure increased cell proliferation and migration via metastasis-related gene changes in vitro in an ovarian cancer cell line [12]. In contrast, intravenous anaesthetics including propofol and midazolam were reported to inhibit cancer cell growth $[13,14]$. Isoflurane enhanced cell proliferation and migration via hypoxia 
inducible factor- $1 \alpha$ (HIF-1 $\alpha)$ and matrix metalloproteinase 9 (MMP9) in prostate [13] and ovarian cancer cells [12]. It is well known that HIF-1 $\alpha$ has an essential role in cancer cell proliferation and invasion $[15,16]$ whilst MMP9 is crucial in tumour migration and progression [17].

MicroRNAs (miRNAs) are noncoding short nucleotides that affect cancer cell biology via protein post-transcription. miRNAs control the normal cell and cancer cell biology [18]. Interestingly, miR-138 [19] and -210 [20] regulate HIF genes, while miR-335 was reported to control MMP9 in glioma [21] and has been suggested to play a role in breast cancer progression [22,23]. However, the potential role of these miRNAs on ovarian cancer development and progression is limited and, furthermore, it remains largely unknown whether inhalational anaesthetics can affect ovarian cancer cell malignancy via miRNA expression changes. The present study, therefore, aims to investigate the potential role of the miRNAs miR-138, -210 and -335 and their downstream effector, HIF- $1 \alpha$ and MMP9, as well as changes induced by sevoflurane or desflurane, which are commonly used clinically on ovarian cancer cell biology and malignancy.

\section{Results}

2.1. Sevoflurane and Desflurane Increased SKOV3 Cell Proliferation and Migration

\subsubsection{Cell Migration}

First, the changes in cell proliferation and migration after anaesthetic exposure were evaluated with a wound healing assay, Cell Counting Kit-8 (CCK8) assay and Ki67 immunofluorescent staining. Sevoflurane or desflurane exposure exhibited procancer effects in SKOV3 cells. In the wound healing assay, sevoflurane and desflurane significantly increased the "wound" gap closure ratio at $4 \mathrm{~h}$ (sevoflurane $16.82 \pm 1.01, p<0.001$; desflurane $14.68 \pm 1.61, p=0.036$ vs. control $12.34 \pm 1.68$ ) and at $8 \mathrm{~h}$ (sevoflurane $43.59 \pm 2.09$, $p<0.001$; desflurane $43.01 \pm 1.30, p<0.001$ vs. control $34.36 \pm 1.86$ ) after gas exposure compared to the control group. There were no differences between sevoflurane and desflurane $(n=6)$ (Figure 1a,b).
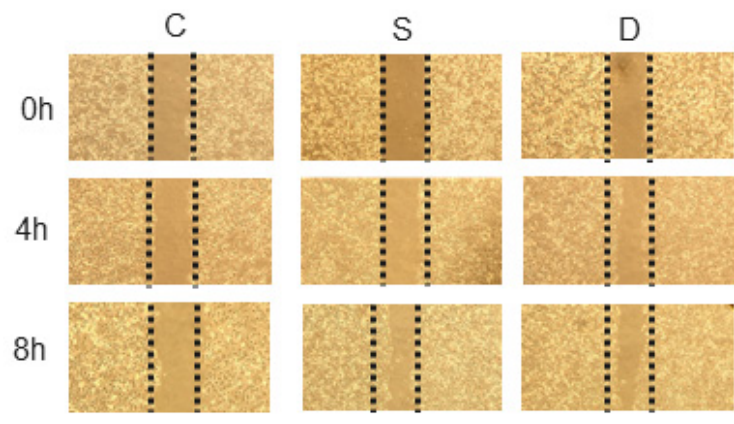

(a)

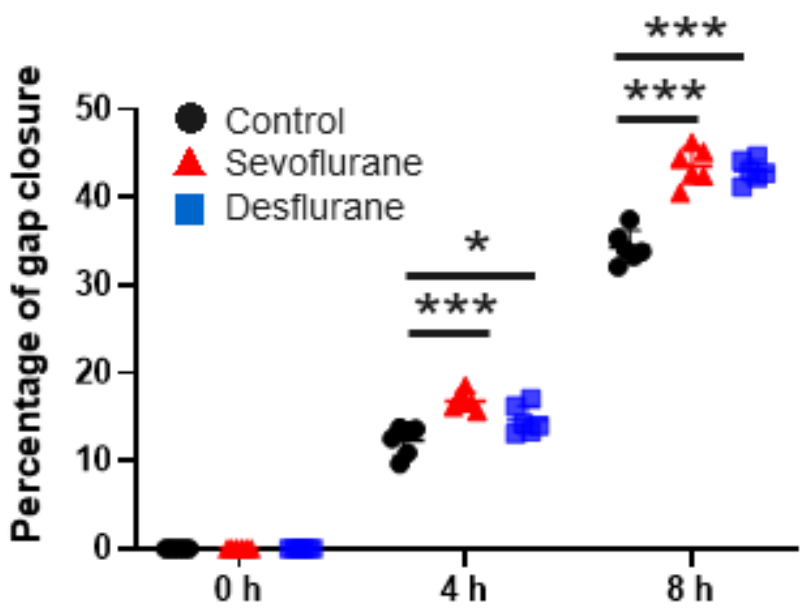

(b)

Figure 1. Cont. 


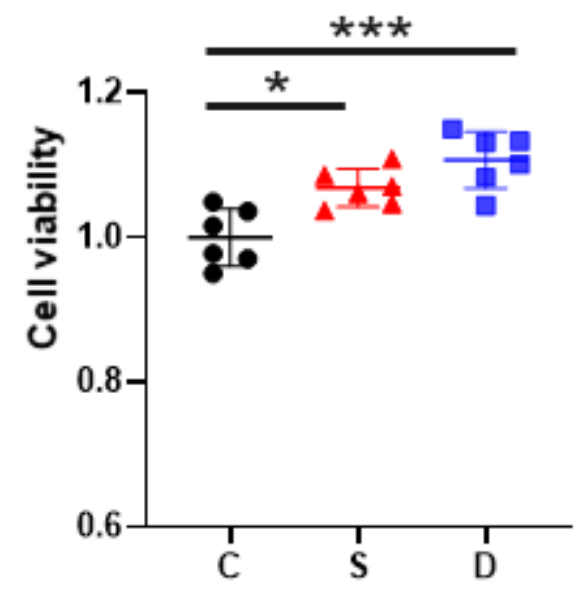

(c)

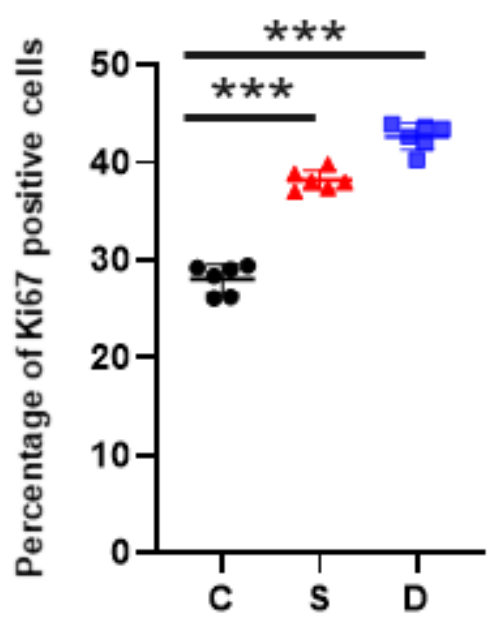

(e)

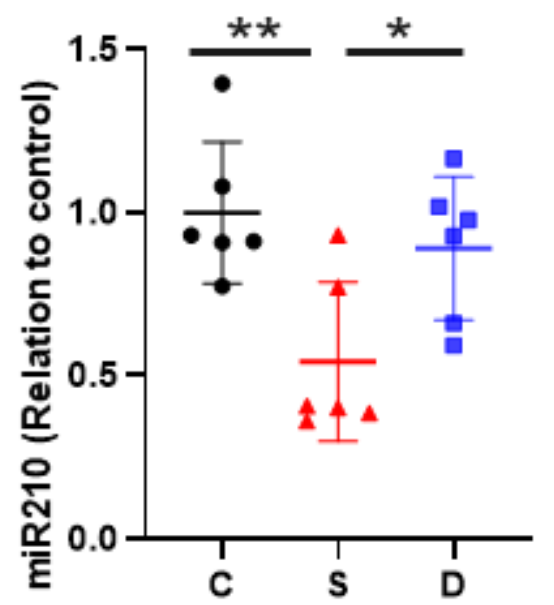

(g)

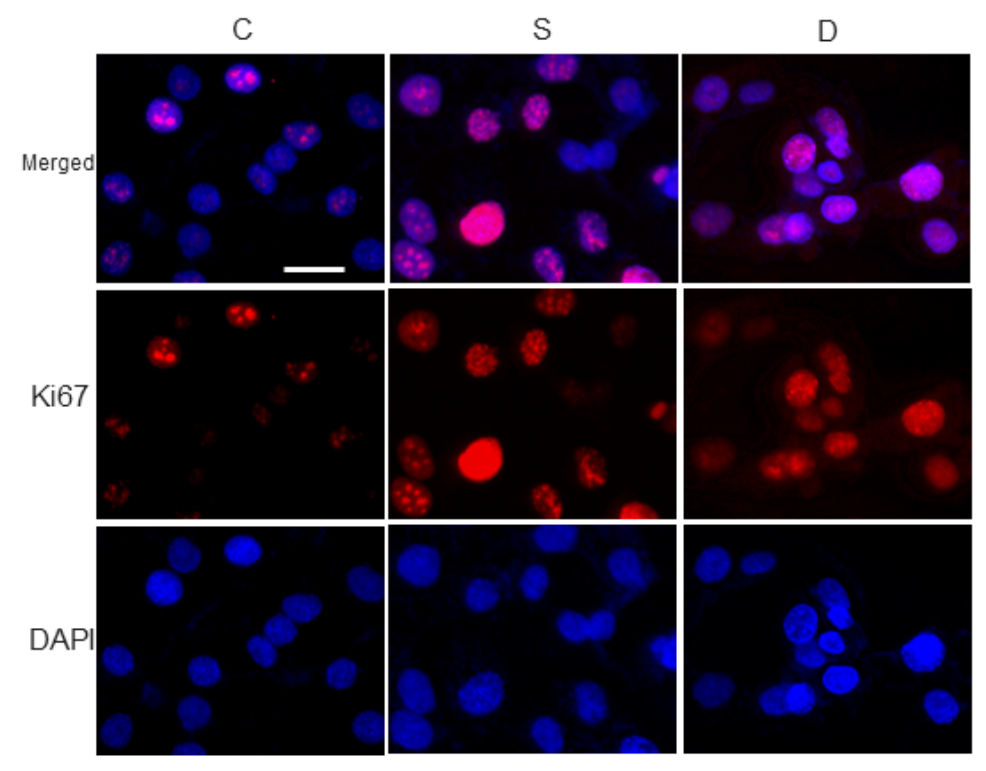

(d)

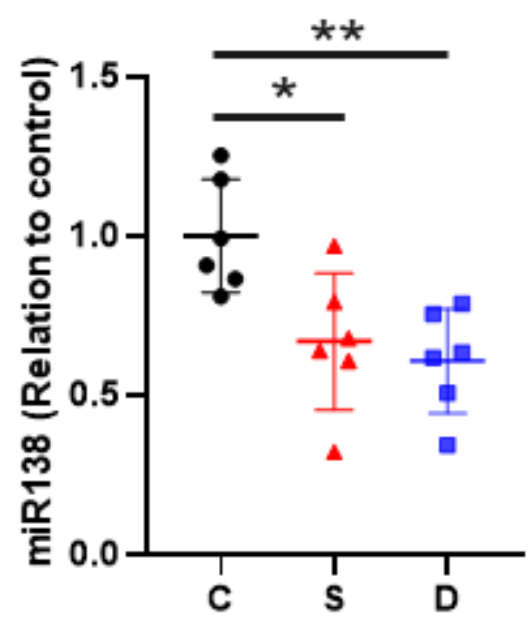

(f)

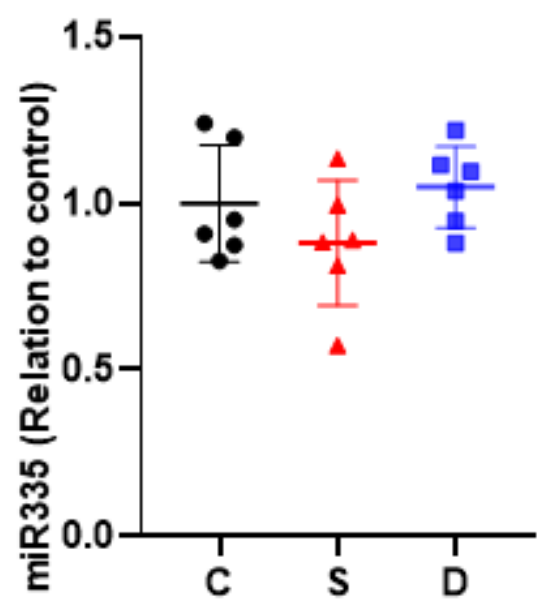

(h)

Figure 1. The changes of cell viability and miRNAs after inhalational anaesthesia. (a) SKOV3 cell migration analysis with wound healing assay after $2 \mathrm{~h}$ of inhalational anaesthesia: control (left), 3.6\% sevoflurane (middle) and 10.4\% desflurane (right), at $0 \mathrm{~h}$ later (upper), $24 \mathrm{~h}$ later (middle) and $48 \mathrm{~h}$ later (bottom). The microscopic images at 0,24 and $48 \mathrm{~h}$ after general 
anaesthesia. (b) The comparison between anaesthetics in percentage of gap closure by wound healing assay. (c) Cell proliferation analysis with CCK8 assay relative to control group. (d) Ki67 immunofluorescence staining: Ki67 (red), marker for cell proliferation, in control (left), sevoflurane- (middle) and desflurane-treated (right) SKOV3 cells, counterstained with DAPI (blue); $\times 20$ magnification, scale bar $=20 \mu \mathrm{m}$. (e) Comparison of percentage of Ki67 positive cells at $24 \mathrm{~h}$ after anaesthesia exposure. (f-h) miRNA expressions evaluated with qRT-PCR compared to control group just after anaesthesia exposure: (f) miR-138 (HIF-1 $\alpha$ regulator), (g) miR-210 (HIF-1 $\alpha$ regulator) and (h) miR-335 (MMP9 regulator). Data showed as plots and mean $\pm \mathrm{SD} .{ }^{*} p<0.05,{ }^{* *} p<0.01,{ }^{* * *} p<0.001, n=6$, one-way ANOVA with Tukey-Kramer compared to the control group. C: control, S: sevoflurane, D: desflurane and CCK8: cell count kit 8.

\subsubsection{Cell Proliferation}

Cell proliferation at $24 \mathrm{~h}$ after gas exposure was promoted by both anaesthetic agents in the CCK8 assay (sevoflurane 1.07 $\pm 0.03, p=0.012$; desflurane $1.11 \pm 0.04, p<0.001$ vs. control $1.00 \pm 0.04$ ) after gas exposure compared to the control group. There were no differences between sevoflurane and desflurane $(n=6)$ (Figure 1c).

Ki67 immunofluorescence staining showed that cell proliferation after sevoflurane and desflurane exposure significantly increased (sevoflurane $38.22 \pm 1.01, p<0.001$; desflurane $42.69 \pm 1.35, p<0.001$ vs. control $28.08 \pm 1.52)$. There was a significant difference between sevoflurane and desflurane $(p<0.001, n=6)$ (Figure 1d,e).

\subsection{Sevoflurane Downregulated miR-138 and -210 Expression Whereas Desflurane Downregulated Only miR-138 Expression in SKOV3 Cells miRNA Changes after Anaesthesia}

To find the miRNAs responsible for the viability changes after anaesthetic exposure, miR-138, -210 and -335 were selected for further investigation. Both sevoflurane and desflurane significantly suppressed miR-138 expression in SKOV3 cells (sevoflurane $0.67 \pm 0.21, p=0.020$; desflurane $0.61 \pm 0.16, p=0.006$ vs. control $1.00 \pm 0.18, n=6$, Figure 1f). Sevoflurane exposure significantly decreased miR-210 expression compared to the other groups (sevoflurane $0.54 \pm 0.24, p=0.009$; desflurane $0.89 \pm 0.22, p=0.686$ vs control $1.00 \pm 0.22$ ). There was a significant difference between sevoflurane and desflurane $(p=0.046, n=6$, Figure 1g) and miR-335 expression was unchanged after any anaesthetic exposure (Figure $1 \mathrm{~h}$ ).

\subsection{The Mimic of miR-138 and -210 Inhibited Cell Proliferation and Migration after Sevoflurane and Desflurane Exposure}

\subsubsection{Cell Migration Ability after the Mimic Administration of miR-138 and -210}

To ascertain the involvement of miR-138 and -210 to cell biology changes, the mimics of these miRNAs were transfected to SKOV3 cells before anaesthetic exposure. miR-210 mimic treatment decreased "wound" gap closure ratio at $4 \mathrm{~h}$ and $8 \mathrm{~h}$ after air exposure as shown in Figure 2a,b ( $4 \mathrm{~h}$ after the exposure: control + miR-210 mimic: $8.90 \pm 0.89, p=0.008$ vs. control: $12.42 \pm 1.47 ; 8 \mathrm{~h}$ after the exposure: control + miR-210 mimic: $23.91 \pm 2.51$, $p<0.001$ vs. control: $35.99 \pm 1.65, n=6)$, and miR-138 mimic treatment decreased at $8 \mathrm{~h}$ after the exposure (control + miR-138 mimic: $31.04 \pm 2.62, p=0.003$ vs. control: $35.99 \pm 1.65$, $n=6)$. 
Oh

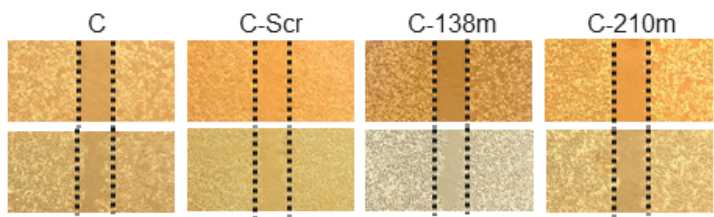

(a)

Oh

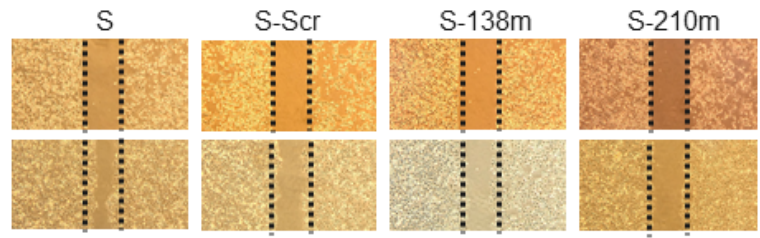

oh

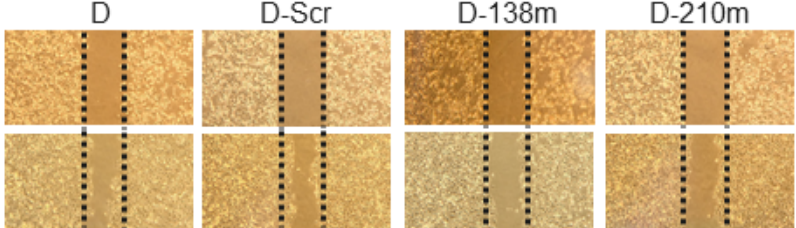

(e)

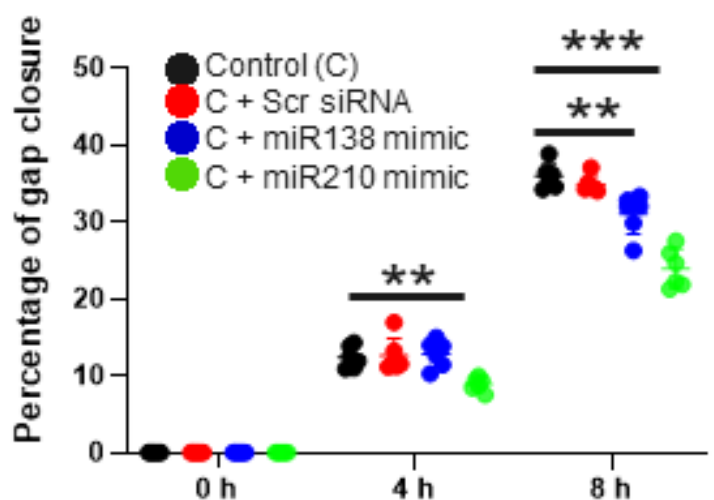

(b)

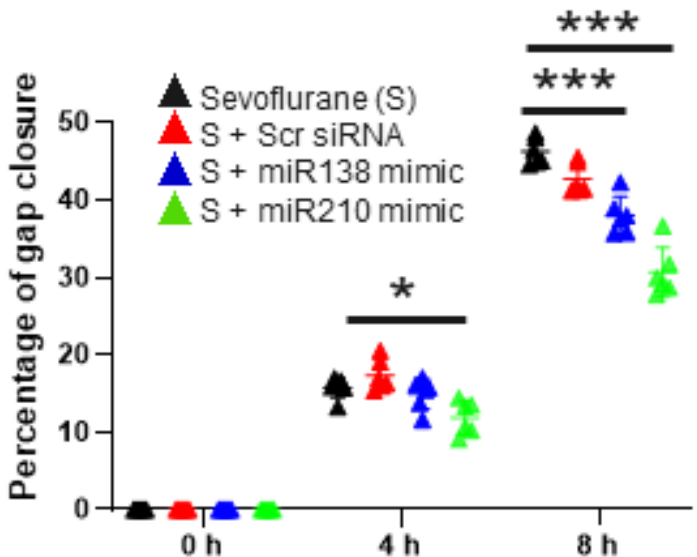

(d)

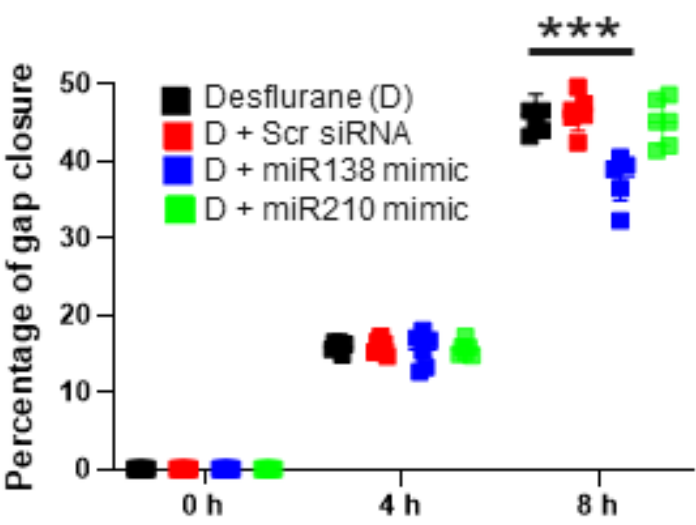

(f)

Figure 2. Cont. 


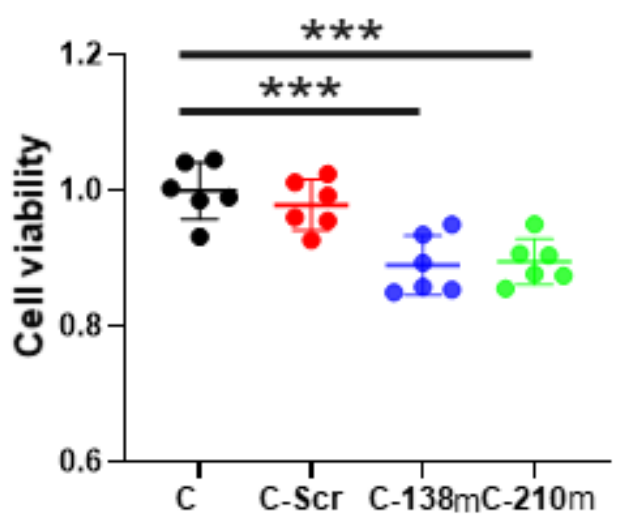

(g)

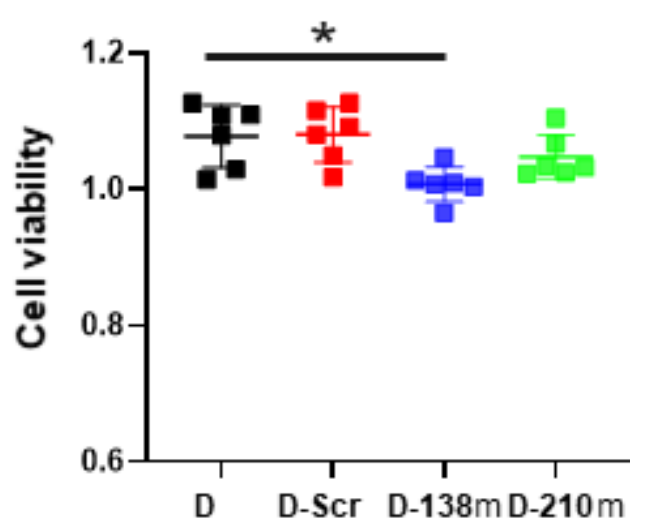

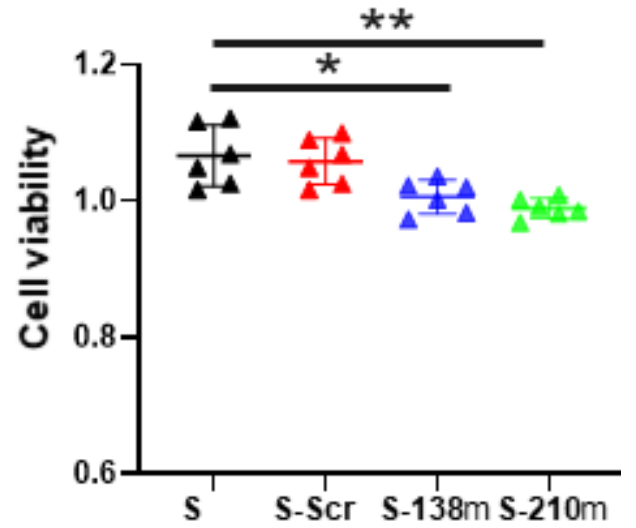

(h)

(i)

Figure 2. The changes of cell migration and proliferation after inhalational anaesthesia with mimic miRNA pretreatment. (a-f) SKOV3 cell migration analysis with wound healing assay after $2 \mathrm{~h}$ of inhalational anaesthesia with miRNA inhibition pretreatment at $0 \mathrm{~h}$ (upper) and $8 \mathrm{~h}$ (bottom) after anaesthesia. (a) The microscopic images after control anaesthesia. (b) The comparison of gap closure percentage with control anaesthesia and mimic miRNA pretreatment. (c) The microscopic images after 3.6\% sevoflurane anaesthesia with mimic miRNA pretreatment. (d) The comparison of gap closure percentage with $3.6 \%$ sevoflurane anaesthesia and mimic miRNA pretreatment. (e) The microscopic images after $10.4 \%$ desflurane anaesthesia with mimic miRNA pretreatment. (f) The comparison of gap closure percentage with $10.4 \%$ desflurane anaesthesia and mimic miRNA pretreatment. (g-i) Cell proliferation analysis with CCK 8 assay with anaesthesia and mimic miRNA pretreatment relative to each control group at $24 \mathrm{~h}$ after exposure: $(\mathrm{g})$ control anaesthesia, (h) $3.6 \%$ sevoflurane anaesthesia and (i) 10.4\% desflurane anaesthesia. Data showed as plots and mean \pm SD. ${ }^{*} p<0.05,{ }^{* *} p<0.01,{ }^{* * *} p<0.001$, $n=6$. One-way ANOVA with Tukey-Kramer compared to each control group. C: control, S: sevoflurane, D: desflurane, CCK8: Cell Counting Kit-8, Scr: scrambled miRNA, 138m: miR-138 mimic and 210m: miR-210 mimic.

2.3.2. Cell Migration Ability after the Mimic Administration of miR-138 and -210 with Sevoflurane Exposure

Under sevoflurane exposure, the same tendency was observed as summarized in Figure 2c,d; miR-210 mimic treatment decreased "wound" gap closure ratio at $4 \mathrm{~h}$ and $8 \mathrm{~h}$ after the exposure ( $4 \mathrm{~h}$ after the exposure: sevoflurane + miR-210 mimic $11.91 \pm 2.16$, $p=0.010$ vs. sevoflurane $15.75 \pm 1.31 ; 8 \mathrm{~h}$ after the exposure: sevoflurane $+\mathrm{miR}-210 \mathrm{mimic}$ $30.66 \pm 3.21, p<0.001$ vs. sevoflurane $46.28 \pm 1.74, n=6$ ), and miR-138 mimic treatment decreased at $8 \mathrm{~h}$ after the exposure (sevoflurane + miR-138 mimic: $38.03 \pm 2.42, p<0.001$ vs. sevoflurane: $46.28 \pm 1.74, n=6$ ). 
2.3.3. Cell Migration Ability after the Mimic Administration of miR-138 and -210 with Desflurane Exposure

With desflurane exposure, only miR-138 mimic treatment suppressed cell migration at $8 \mathrm{~h}$ after the exposure (desflurane $+\operatorname{miR}-138$ mimic $38.03 \pm 2.42, p<0.001$ vs. desflurane $46.03 \pm 2.63, n=6$, Figure 2e,f).

2.3.4. Cell Proliferation after the Mimic Administration of miR-138 and -210 with Anaesthetic Exposure

Considering cell proliferation analysis with the CCK8 assay at $2 \mathrm{~h}$ after the exposure, miR-138 mimic treatment reduced cell proliferation at any anaesthetic exposure, but miR210 mimic treatment decreased under control and sevoflurane exposure, not desflurane exposure $(n=6$, Figure $2 \mathrm{~g}, \mathrm{~h}, \mathrm{i})$.

2.4. Sevoflurane and Desflurane Exposure Enhanced HIF-1 $\alpha$ Protein Expression Which Was Reverted by miR-138 and-210 Mimic Treatment

2.4.1. Immunofluorescent Staining Analysis

miR-138 and -210 are reported to control HIF-1 $\alpha$ expression, a key factor of cancer malignancy. As shown in Figure 3a,b, HIF-1 $\alpha$ expression in cytoplasm elevated after sevoflurane and desflurane exposure (sevoflurane $1.57 \pm 0.23, p<0.001$, desflurane $1.29 \pm 0.14$, $p=0.019$, vs. control $1.00 \pm 0.08, n=6$ ), which significantly lessened with miR-138 and -210 mimic treatment at any anaesthetic condition (control $1.00 \pm 0.08$, control + miR-210 mimic $0.77 \pm 0.12, p=0.003$, control $+\operatorname{miR}-138$ mimic $0.85 \pm 0.08, p=0.065$, vs. control $1.00 \pm 0.08$; sevoflurane + miR-210 mimic $0.58 \pm 0.14, p<0.001$, sevoflurane + miR-138 mimic $0.59 \pm 0.14, p<0.001$, vs. sevoflurane $1.57 \pm 0.23$; desflurane + miR-210 mimic $0.77 \pm 0.19, p<0.001$, desflurane + miR-138 mimic $0.78 \pm 0.10, p<0.001$, vs. desflurane $1.29 \pm 0.14, n=6)$.

\subsubsection{Western Blotting Analysis}

The Western blotting analysis showed similar trend changes but did not reach any statistical significance (control + miR-210 mimic $0.92 \pm 0.11, p=0.905$, control + miR138 mimic $0.78 \pm 0.26, p=0.231$ vs. control $1.00 \pm 0.15$; sevoflurane + miR-210 mimic $1.07 \pm 0.13, p=0.961$, sevoflurane $+\operatorname{miR}-138$ mimic $0.87 \pm 0.33, p=0.103$ vs. sevoflurane $1.11 \pm 0.12$; desflurane + miR-210 mimic $1.07 \pm 0.09, p=0.936$, desflurane + miR-138 mimic $0.81 \pm 0.28, p=0.224$ vs. desflurane $1.01 \pm 0.18, n=6-7$, Figure $3 c, d$ ). 


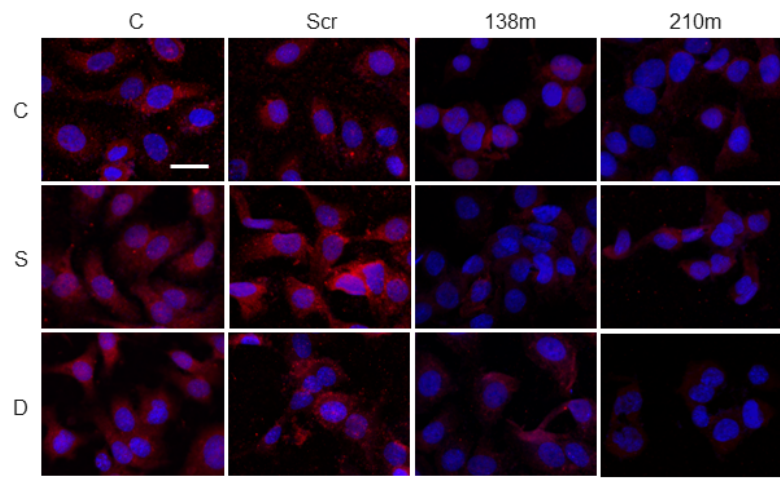

(a)

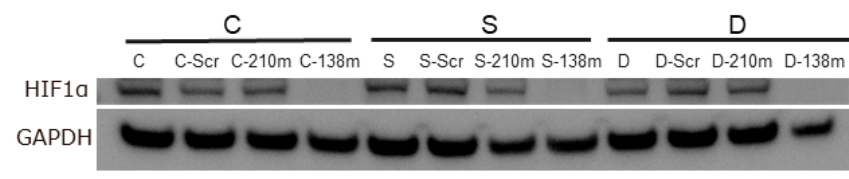

(c)

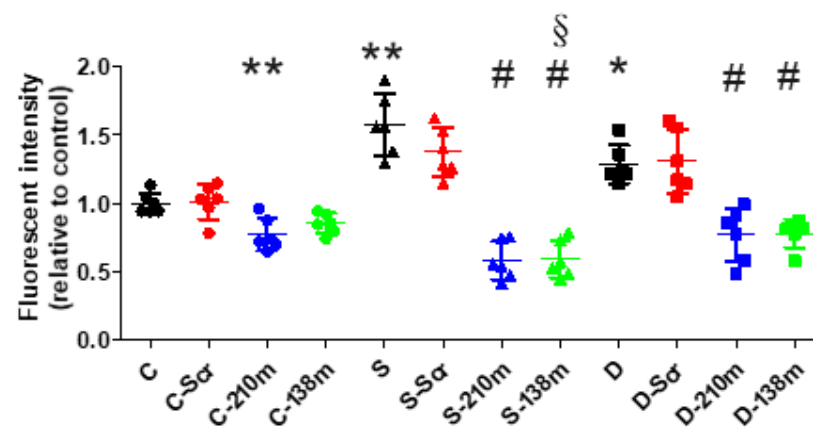

(b)

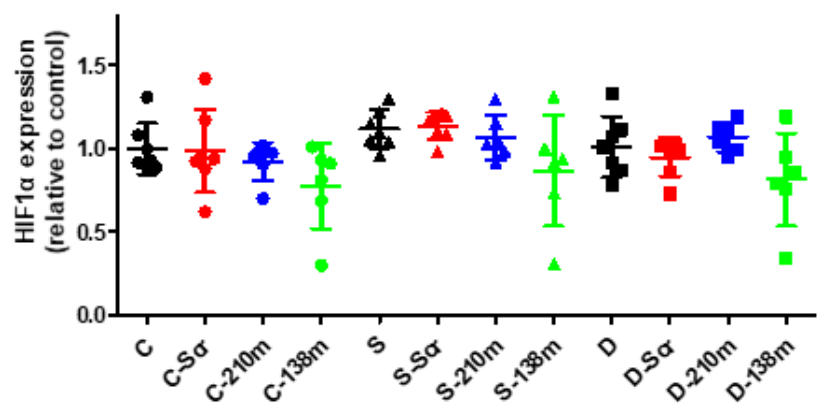

(d)

Figure 3. The HIF- $1 \alpha$ expression changes after inhalational anaesthesia with mimic miRNA pretreatment. (a) HIF- $1 \alpha$ immunofluorescence staining, HIF-1 $\alpha$ (red) in control (left), sevoflurane- (middle) and desflurane-treated (right) SKOV3 cells with mimic miRNA pretreatment, counterstained with DAPI (blue); $\times 20$ magnification, scale bar $=20 \mu \mathrm{m}$. $(\mathbf{b})$ The comparison of the HIF- $1 \alpha$ immunofluorescence intensity with each anaesthetic and mimic miRNA pretreatment. (c) The representative image of HIF- $1 \alpha$ Western blotting analysis with anaesthesia and mimic miRNA pretreatment. (d) The comparison of HIF-1 $\alpha$ expression in Western blotting after anaesthesia and mimic miRNA pretreatment. Data showed as plots and mean $\pm \mathrm{SD} .{ }^{*} p<0.05,{ }^{* *} p<0.01, n=6$. One-way ANOVA with Tukey-Kramer compared to the control group, \# $p<0.05$; one-way ANOVA with Tukey-Kramer compared to each control group, $\S p<0.05$; one-way ANOVA with Tukey-Kramer compared to the control group with the same mimic miRNA pretreatment. C: control, S: sevoflurane, D: desflurane, CCK8: Cell Counting Kit-8, Scr: scrambled miRNA, 138m: miR-138 mimic and 210m: miR-210 mimic.

\section{Discussion}

The present study with an ovarian cancer cell line (SKOV3) demonstrated that inhalational anaesthetic agents exert procancer effects via miR-138 and/or miR-210/HIF- $1 \alpha$ modulations. Furthermore, miR-210 and -138 mimic administration attenuated the protumour effects of inhalational anaesthetics with HIF-1 $\alpha$ suppression. Taken together, both sevoflurane and desflurane may promote cancer cell migration and proliferation by direct HIF-1 $\alpha$ upregulation via miR-138 and -210 suppression.

Our data demonstrated that sevoflurane and desflurane, commonly used for surgical anaesthesia, may contribute to the risk of cancer recurrence after surgery that may be involved with the HIF-1 $\alpha$ signalling pathway via miRNA mediation (Figure 4 ). The importance of miRNAs in cancer cell biology is well documented in the literature. miRNAs can be pro- or anticancer regulators due to their complex functions because a single miRNA can regulate more than 100 target genes and proteins [24]. miRNAs were reported to regulate cancer cell proliferation and invasion in ovarian cancer cells [25]. Indeed, miR630 promoted SKOV3 cell proliferation and migration by targeting Krüppel-like factor 6 (KLF6) [26]. miR-18b accelerated invasion and migration of ovarian cancer cells via phosphatase and tensin homolog (PTEN) [27]. In contrast, miR-34 reduced the mesenchymal-to- 
epithelial transition (MET) protein levels and suppressed cancer cell migration, invasion and proliferation in p53-null SKOV3 cells [28]. miR-335 is reported to control MMP9 in glioma [21], as suggested in breast cancer [22,23]. Furthermore, miRNA changes after inhalational anaesthetic exposure can modulate cancer cell biology. For example, sevoflurane can inhibit cell migration and invasion in colon cancer cells via the ERK/MMP9 pathway by regulating miR-203 [29]. On the other hand, desflurane enhanced colorectal cancer malignancy via the miR-34a/lysyl oxidase-like 3 axis [30]. Our data clearly demonstrated that sevoflurane and desflurane both promoted SKOV3 cancer cells, one of the ovarian cancer types, and malignancy via miR-138 and/or -210. The discrepancy was likely due to the differences of experimental conditions; the concentrations of sevoflurane or desflurane were exposed to cancer cells for $6 \mathrm{~h}$ in those previous studies $[29,30]$, which caused cancer cell death due to their toxicity of cumulative doses. It is worth pointing out that those previous studies were designed beyond clinical settings as anaesthesia was administered for $6 \mathrm{~h}$ and this is exceedingly rare for cancer surgery clinically. Therefore, the translational value of those studies is very questionable.

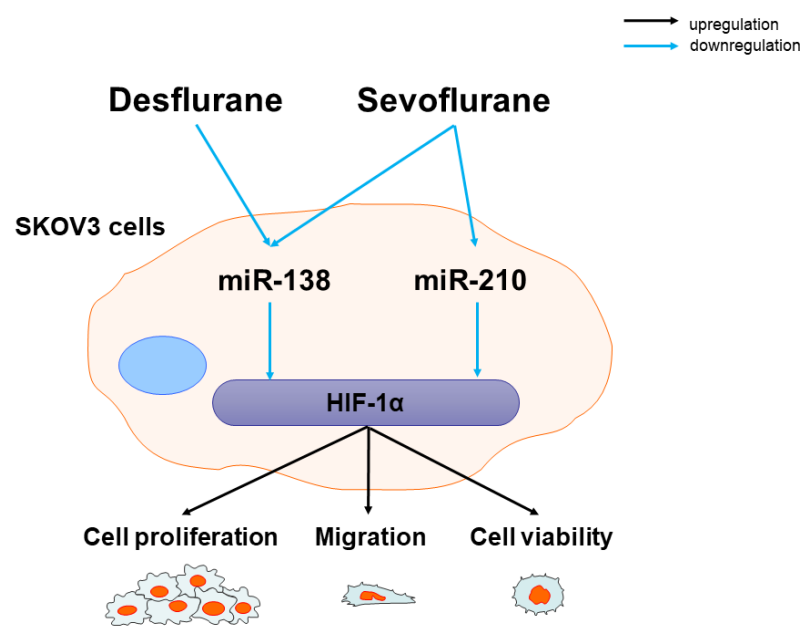

Figure 4. Inhalational anaesthetics enhanced SKOV3 cell malignancy via downregulation of anticancer miRNA expressions. Sevoflurane and desflurane exposure to SKOV3 cells increase SKOV3 cell proliferation and migration via HIF- $1 \alpha$ by miR-138 downregulation. Only sevoflurane decreased miR-210 expression leading to an enhancement of SKOV3 cell malignancy via HIF-1 $\alpha$.

Several studies showed that HIF- $1 \alpha$ was directly regulated by miRNAs including miR138 [19] and miR-210 [20]. Our data showed that sevoflurane and desflurane downregulated the expression of miR-138 in SKOV3 cells. miR-138 is a tumour suppressor in several types of cancer cells [31-34]. miR-138 expression is downregulated in numerous cancers including glioblastoma [35], and its downregulation can suppress cell proliferation, invasion and migration as a tumour-suppressor gene via targeting of Histone's H2A variant (H2AX) in cervical cancer cells [36] or via Sry-Related HMG-BOX-4 (SOX4) in ovarian cancer cells [35]. The expression level of miR-138 correlates with ovarian cancer prognosis and, indeed, the level of miR-138 in patients with lymphatic metastasis was lower than that in patients without lymphatic metastasis [32]. Patients with low miR-138 expression tend to be in late stage and have malignant phenotypes [35]. miR-138 inhibits the occurrence and development of ovarian cancer by downregulating the expression of SOX12 gene [36] and invasion via SOX 4 and HIF- $1 \alpha$ oncogenic transcriptional factors [37]. HIF- $1 \alpha$ is one of the targets of miR-138 and miR-138 negatively regulates HIF- $1 \alpha$ to suppress proliferation, invasion and migration in melanoma [19,38] and ovarian cancer [37]. miR-210 is not only a tumour-stimulating miRNA but has a dual role as a procancer and anticancer miRNA. miR-210 can act as a tumour suppressor, inhibiting cell proliferation in ovarian cancer [39] and laryngeal squamous cell carcinoma [40]. miR-210 can attenuate cancer cell activity 
through downregulating E2F3, fibroblast growth factor receptor-like 1, homeobox protein Hox-A1, homeobox protein Hox-A9 and Max-binding protein [41-43]. HIF-1 $\alpha$ contains a miR-210 targeting site in its $3^{\prime}$ UTR and is one of miR-210's target genes [20]. Unlike desflurane, we found that sevoflurane also decreased miR-210 expression in this study but both agents were ineffective on miRNA-355. The underlying mechanisms of these differences remain unknown and warrant further study.

Inhalational anaesthetic isoflurane was reported to increase ovarian cancer cell proliferation and migration [44], and all commonly used inhalational anaesthetics can even alter cancer-metastasis-related genes [12]. All these may influence the ovarian cancer surgical outcomes, although it was shown that desflurane was associated with a lower recurrence rate compared with sevoflurane, but underlying mechanisms for such differences remain unknown [45]. Previous studies demonstrated that inhalational anaesthetics could be procancer factors in other cancer types. Isoflurane exposure to prostate cancer cells promoted HIF-1a and its downstream effector expressions including vascular endothelial growth factor (VEGF), and it increased HIF- $1 \alpha$ expression in a concentration- and time-dependent manner; HIF- $1 \alpha$ was translocated from the cytoplasm to the nucleus as a transcriptional factor, resulting in promoted proliferation and invasion [13]. In ovarian cancer cells, CXC chemokine receptor 2 (CXCR2), VEGF-A, MMP11 and transforming growth factor $\beta$ (TGF$\beta)$ expressions were all significantly increased by inhalational anaesthetics, indicating the activation of key molecular mediators of cancer cell proliferation, cell migration and angiogenesis [12]. HIF- $1 \alpha$ has been identified as one of the key regulators in tumour progression, cancer cell proliferation, invasion and angiogenesis $[46,47]$ by the activation of the phosphoinositide 3-kinase/Akt/mammalian target of rapamycin (PI3K/Akt/mTOR) and mitogen-activated protein kinase/extracellular signal-regulated kinase (MAPK/ERK) pathways [48]. The increased HIF- $1 \alpha$ expression has been found in numerous cancer cells [49] and clinically linked with tumour growth, metastasis and poor clinical prognosis [50]. HIF- $1 \alpha$ also regulates the transcription of multi-specific drug efflux transporters leading to chemoresistance [51].

The present study was not free from limitations. Firstly, this is an in vitro study with one cell line of ovarian cancer types. Furthermore, SKOV3 unlikely represents the most common ovarian cancer cell type of high-grade serous carcinoma (HGSC) $[52,53]$ and each of the ovarian cancer cell phenotypes have their own biological characteristics. Thus, further investigations using other cell lines of ovarian cancers are needed to see whether the current findings are also evident in other ovarian cancer cells types. If so, then the onco-effects of inhalational anaesthetics are also needed to be verified in a clinic scenario mode and an in vivo setting. Secondly, the wound healing assay was used in our study; it measures both cell migration and proliferation. Therefore, the separate effect of anaesthetics studied on migration or proliferation warrants further study. Thirdly, the mechanisms as to why sevoflurane exposure suppressed miR-138 and -210 expression while desflurane only suppressed miR-138 expression (Figure 1) remain unknown. Whether this discrepancy is due to their very different chemical structure, physical properties and anaesthetic potency is elusive. Interestingly, this is in line with our previous findings showing metastatic gene expressions induced by them in SKOV3 were also different [12]. Furthermore, we did not evaluate the HIF- $1 \alpha$ downstream effectors and, hence, their effects on cancer cell biology are unknown. Lastly, it is worth pointing out that protein expression analysis with miRNA-mimic administration under anaesthetic exposure was not conclusive when compared to immunostaining (Figure 3). It was very likely that there were considerably more experimental procedures involved in Western blot analyses which may distort the results whilst, arguably, it may also mean that whether in situ immunostaining is more reliable than Western blot is an open question.

In summary, our data indicated that sevoflurane or desflurane promoted SKOV3 cell migration and proliferation via miR-138 and -210 suppression. Although the clinical significance of our work requires further investigation, this study undoubtedly enhances our understanding of the impact of inhalational anaesthesia on cancer cells during the 
perioperative period and provides supporting evidence for the selection of appropriate anaesthetics for the benefit of patients' prognosis after surgery.

\section{Materials and Methods}

\subsection{Cell Culture}

SKOV3 human ovarian epithelial carcinoma cell line (European Cell Culture Collection, Salisbury, UK) was cultured at $37^{\circ} \mathrm{C}$ in a humidified atmosphere containing $5 \% \mathrm{CO}_{2}$ balanced with air in McCoy's 5A medium (Sigma-Aldrich, Dorset, UK) supplemented with 10\% fetal bovine serum (Thermo Scientific, Epsom, UK), 2 mM L-glutamine (Sigma-Aldrich) and $1 \%$ penicillin (Sigma-Aldrich) for the experiments described below with or without inhalational agent exposure for further analyses.

\subsection{Inhalational Anaesthetic Exposure}

When cultures reached $60 \%$, they were exposed to $21 \% \mathrm{O}_{2}, 5 \% \mathrm{CO}_{2}$ and $3.6 \%$ sevoflurane or $10.3 \%$ desflurane balanced with $\mathrm{N}_{2}$ (BOC, South Humberside, UK) in a purposebuilt $1.5 \mathrm{~L}$ airtight gas chamber, equipped with inlet and outlet valves. The chamber was then placed in an incubator (Galaxy $\mathrm{R} \mathrm{CO}_{2}$ chamber; New Brunswick Scientific, Enfield, CT, USA) at $37^{\circ} \mathrm{C}$ for $2 \mathrm{~h}$. Other cohort cells were exposed to the same concentration gases without any inhalational anaesthetics and served as controls. After exposure, cells were returned to the normal culture incubator for further study. Both sevoflurane and desflurane were set at the equipotent concentrations approximately equal to 1.7 minimum alveolar concentrations in human.

\subsection{Wound Healing Assay}

Cells $\left(2.5 \times 10^{4}\right)$ were seeded into each well (Culture-Insert 3 wells; Ibidi, Martinsried, Germany), incubated for $24 \mathrm{~h}$ before wound was made and then exposed to the experimental gas mixtures as above for $2 \mathrm{~h}$. The gap closure was monitored under the microscope and a digital camera (CK30-SLP; Olympus, Tokyo, Japan) at 0,4 and $8 \mathrm{~h}$ after gas exposure. Images were analysed using Image J version 1.52a software (National Institute of Health, Bethesda, MD, USA).

\subsection{Cell Proliferation Test}

Cells $\left(7 \times 10^{3}\right)$ were seeded in 96-well plates and exposed to the experimental gas mixture. Cell proliferation was assessed by the CCK8 reagent (Sigma-Aldrich) which was read from culture media at $450 \mathrm{~nm}$ (ELx800 Microplate Reader, BioTek Instruments, Winooski, VT, USA) at $24 \mathrm{~h}$ after gas exposure. Cell proliferation was expressed relative to the corresponding control.

\subsection{RNA Extraction and Reverse Transcription}

Immediately after the anaesthetic exposure, total RNA was extracted from cells using QIAzol Lysis Reagent (Qiagen, West Sussex, UK) and an miRNeasy Mini Kit (Qiagen) following the manufacturer's protocols. RNA quantity and quality were assessed using a BioPhotometer (Eppendorf, Stevenage, UK). Samples with an A260/A280 ratio > 1.8 were considered to be sufficient quality for further analysis. A total of $1 \mathrm{ng}$ RNA was converted to cDNA using miScript II RT Kit (Qiagen) with the thermal cycles of $37^{\circ} \mathrm{C}$ for $60 \mathrm{~min}$ and $95^{\circ} \mathrm{C}$ for 5 min (Mastercycler ${ }^{\circledR}$, Eppendolf, Stevenage, UK).

\section{6. $q R T-P C R$}

qRT-PCR was performed with the miScript SYBR Green PCR Kit (Qiagen) and Rotor gene Q system (Qiagen). SNORD44 small nuclear RNA was used as an endogenous control. The specific primers, miR-138-5p, miR-210-3p and miR-335-5p, were purchased from Qiagen. Thermal cycles were as follows: $95^{\circ} \mathrm{C}$ for $15 \mathrm{~min}$ and 40 cycles of $94{ }^{\circ} \mathrm{C}$ for $15 \mathrm{~s}, 55^{\circ} \mathrm{C}$ for $30 \mathrm{~s}$ and $70{ }^{\circ} \mathrm{C}$ for $30 \mathrm{~s}$. Melting curve analysis was used to confirm the specificity of amplification. The relative expressions of miRNAs to SNORD44 were 
determined using the comparative $2^{-\Delta \Delta \mathrm{Ct}}$ method. A 2-fold change or over was considered to be of significance.

\section{7. miRNA Mimic Transfection}

The mimics of miR-138-5p (5'AGCUGGUGUUGUGAAUCAGGCCG) and -210 (5'CUG UGCGUGUGACAGCGGCUGA) were purchased from Qiagen in comparison with All Stars Negative Control siRNA (Qiagen) as the negative control. Cells were transfected with either $50 \mathrm{nM}$ of the mimic or the negative control using the HiPerFect transfection reagent (Qiagen), following the manufacturer's protocols. After $24 \mathrm{~h}$ of transfection, the transfection solution was replaced with fresh medium before the experimental gas exposure.

\subsection{Immunofluorescent Staining}

Cells at $24 \mathrm{~h}$ after gas exposure were fixed in $4 \%$ paraformaldehyde for $10 \mathrm{~min}$ and blocked with $10 \%$ normal donkey serum (Sigma-Aldrich) for $1 \mathrm{~h}$, followed by overnight incubation at $4{ }^{\circ} \mathrm{C}$ in primary antibodies: rabbit polyclonal anti-Ki-67 antibody (1:500; Abcam PLC, Cambridge, UK) and rabbit polyclonal anti-HIF- $1 \alpha$ antibody (Novus Biologicals, Oxford, UK). Cells were incubated in Alexa flour 568-conjugated secondary antibody (ThermoFisher scientific) on the following day. Then, cells were costained for the cell nuclei with Vectashield mounting medium containing nuclear dye $4^{\prime}, 6$-diamidino2-phenylindole-mounting medium (Millipore). Slides were then examined using a BX60 wide-field fluorescence microscope (Olympus, Hamburg, Germany) and AxioCam camera (Zeiss, Oberkochen, Germany) with Zeiss software under $20 \times$ magnification. Images were captured using a camera. Fluorescence intensity was quantified as the mean pixel intensity of relevant antibody staining using Image J (version 1.52a, National Institute of Health). Ten representative regions per slide were randomly selected. Intensity values were calculated and expressed as relative to the control.

\subsection{Western Blotting}

The protein was extracted from cell samples using a cell lysis buffer (Cell Signalling Technology, Hitchin, UK) at $24 \mathrm{~h}$ after gas exposure and quantified with a Bradford protein assay (Bio-Rad Laboratories, Hercules, CA, USA). Then, $60 \mu \mathrm{g}$ of protein of each sample was loaded into NuPAGE ${ }^{\circledR} 4-12 \%$ Bis-Tris Precast Gels (Thermo Scientific) for electrophoresis. After electrophoresis, proteins were transferred onto a polyvinylidenedifluoride membrane using the iBlot ${ }^{\circledR} 2$ Dry Blotting System (Thermo Scientific). Membranes were blocked with $5 \%$ nonfat powdered milk in Tris-buffered saline with Tween for $1 \mathrm{~h}$ at room temperature, then incubated overnight at $4{ }^{\circ} \mathrm{C}$ with rabbit anti-HIF- $1 \alpha$ primary antibody (1:500; Abcam) followed by horseradish peroxidase-linked antirabbit secondary antibody (1:1000; Cell Signalling Technology) for $1 \mathrm{~h}$. Protein bands were visualised using the Enhanced Chemiluminescence system (Santa Cruz, Dallas, TX, USA) and Syngene GeneSnap software (Syngene, Cambridge, UK). The intensity of grey-scale protein bands was assessed using ImageJ software.

\subsection{Statistical Analysis}

All numerical data are presented as dot plots and expressed as mean \pm SD. One-way analysis of variance followed by post-hoc Tukey's test were used for data analyses with Prism version 8.0 (GraphPad Software, San Diego, CA, USA). A $p$ value less than 0.05 was considered to be a statistical significance.

\section{Conclusions}

In conclusion, our data demonstrated that inhalational anaesthetics enhanced some ovarian cancer cell biology via miRNA downregulation. The regulatory mechanisms of HIF- $1 \alpha$ expression via miRNAs may contribute to the detrimental effects of inhalational anaesthetics and hence worsen cancer outcomes. This research is a proof-of-concept study with one cell line. In order to investigate "common and general onco-effects of inhalational 
agents", more cell lines need to be considered in future studies. These data may warrant more research to refine optimal anaesthetic regimens for cancer patients including ovarian cancer sufferers.

Author Contributions: Conceptualization, D.M.; methodology, M.I. (Masashi Ishikawa), M.I. (Masae Iwasaki), H.Z., C.H., Q.S., and J.S.; software, M.I. (Masae Iwasaki), H.Z. and D.M.; validation, M.I. (Masashi Ishikawa), M.I. (Masae Iwasaki), H.Z. and D.M.; formal analysis, M.I. (Masashi Ishikawa), M.I. (Masae Iwasaki), H.Z. and D.M.; investigation, M.I. (Masashi Ishikawa), M.I. (Masae Iwasaki), H.Z., A.S. and D.M.; resources, H.Z. and D.M.; data curation, M.I. (Masashi Ishikawa), M.I. (Masae Iwasaki), H.Z. and D.M.; writing-original draft preparation, M.I. (Masashi Ishikawa), M.I. (Masae Iwasaki) and D.M.; writing—review and editing, M.I. (Masashi Ishikawa), M.I. (Masae Iwasaki), H.Z., A.S. and D.M.; visualization, M.I. (Masashi Ishikawa), M.I. (Masae Iwasaki) and D.M.; supervision, H.Z., A.S. and D.M.; project administration, H.Z. and D.M.; funding acquisition, M.I. (Masashi Ishikawa) and D.M. All authors have read and agreed to the published version of the manuscript.

Funding: This research was funded by ONO PHARMACEUTICAL CO., LTD., Osaka, Japan (ONOS20190517001) (to M.I.) and BOC Chair grant, Royal College of Anaesthetists, London, UK (to D.M.).

\section{Institutional Review Board Statement: Not applicable.}

Informed Consent Statement: Not applicable.

Conflicts of Interest: The authors declare no conflict of interest.

\section{References}

1. Kim, A.; Ueda, Y.; Naka, T.; Enomoto, T. Therapeutic strategies in epithelial ovarian cancer. J. Exp. Clin. Cancer Res. 2012, 31, 14. [CrossRef]

2. Bray, F.; Ferlay, J.; Soerjomataram, I.; Siegel, R.L.; Torre, L.A.; Jemal, A. Global cancer statistics 2018: GLOBOCAN estimates of incidence and mortality worldwide for 36 cancers in 185 countries. CA Cancer J. Clin. 2018, 68, 394-424. [CrossRef]

3. Narod, S. Can advanced-stage ovarian cancer be cured? Nat. Rev. Clin. Oncol. 2016, 13, 255-261. [CrossRef]

4. Ramalingam, P. Morphologic, Immunophenotypic, and Molecular Features of Epithelial Ovarian Cancer. Oncology 2016, 30, 166-176. [PubMed]

5. Mehlen, P.; Puisieux, A. Metastasis: A question of life or death. Nat. Rev. Cancer 2006, 6, 449-458. [CrossRef]

6. Lee, J.W.; Shahzad, M.M.; Lin, Y.G.; Armaiz-Pena, G.; Mangala, L.S.; Han, H.D.; Kim, H.S.; Nam, E.J.; Jennings, N.B.; Halder, J.; et al. Surgical stress promotes tumor growth in ovarian carcinoma. Clin. Cancer Res. 2009, 15, 2695-2702. [CrossRef] [PubMed]

7. Perry, N.J.S.; Buggy, D.; Ma, D. Can Anesthesia Influence Cancer Outcomes After Surgery? JAMA Surg. 2019, 154, 279-280. [CrossRef]

8. Enlund, M.; Berglund, A.; Andreasson, K.; Cicek, C.; Enlund, A.; Bergkvist, L. The choice of anaesthetic-Sevoflurane or propofol-And outcome from cancer surgery: A retrospective analysis. Ups. J. Med. Sci. 2014, 119, 251-261. [CrossRef] [PubMed]

9. Jun, I.J.; Jo, J.Y.; Kim, J.I.; Chin, J.H.; Kim, W.J.; Kim, H.R.; Lee, E.H.; Choi, I.C. Impact of anesthetic agents on overall and recurrence-free survival in patients undergoing esophageal cancer surgery: A retrospective observational study. Sci Rep. 2017, 7, 14020. [CrossRef]

10. Zheng, X.; Wang, Y.; Dong, L.; Zhao, S.; Wang, L.; Chen, H.; Xu, Y.; Wang, G. Effects of propofol-based total intravenous anesthesia on gastric cancer: A retrospective study. Onco Targets Ther. 2018, 11, 1141-1148. [CrossRef] [PubMed]

11. Wu, Z.F.; Lee, M.S.; Wong, C.S.; Lu, C.H.; Huang, Y.S.; Lin, K.T.; Lou, Y.S.; Lin, C.; Chang, Y.C.; Lai, H.C. Propofol-based Total Intravenous Anesthesia Is Associated with Better Survival Than Desflurane Anesthesia in Colon Cancer Surgery. Anesthesiology 2018, 129, 932-941. [CrossRef]

12. Iwasaki, M.; Zhao, H.; Jaffer, T.; Unwith, S.; Benzonana, L.; Lian, Q.; Sakamoto, A.; Ma, D. Volatile anaesthetics enhance the metastasis related cellular signalling including CXCR2 of ovarian cancer cells. Oncotarget 2016, 7, 26042-26056. [CrossRef]

13. Huang, H.; Benzonana, L.L.; Zhao, H.; Watts, H.R.; Perry, N.J.; Bevan, C.; Brown, R.; Ma, D. Prostate cancer cell malignancy via modulation of HIF-1alpha pathway with isoflurane and propofol alone and in combination. Br. J. Cancer 2014, 111, 1338-1349. [CrossRef]

14. Wang, C.; Datoo, T.; Zhao, H.; Wu, L.; Date, A.; Jiang, C.; Sanders, R.D.; Wang, G.; Bevan, C.; Ma, D. Midazolam and Dexmedetomidine Affect Neuroglioma and Lung Carcinoma Cell Biology In Vitro and In Vivo. Anesthesiology 2018, 129, 1000-1014. [CrossRef]

15. Wigerup, C.; Pahlman, S.; Bexell, D. Therapeutic targeting of hypoxia and hypoxia-inducible factors in cancer. Pharmacol. Ther. 2016, 164, 152-169. [CrossRef]

16. Minet, E.; Michel, G.; Remacle, J.; Michiels, C. Role of HIF-1 as a transcription factor involved in embryonic development, cancer progression and apoptosis (review). Int J. Mol. Med. 2000, 5, 253-259. [CrossRef] [PubMed]

17. Ala-aho, R.; Kahari, V.M. Collagenases in cancer. Biochimie 2005, 87, 273-286. [CrossRef] [PubMed] 
18. Jansson, M.D.; Lund, A.H. MicroRNA and cancer. Mol. Oncol. 2012, 6, 590-610. [CrossRef] [PubMed]

19. Qiu, H.; Chen, F.; Chen, M. MicroRNA-138 negatively regulates the hypoxia-inducible factor 1alpha to suppress melanoma growth and metastasis. Biol. Open 2019, 8. [CrossRef] [PubMed]

20. Wang, H.; Flach, H.; Onizawa, M.; Wei, L.; McManus, M.T.; Weiss, A. Negative regulation of Hif1a expression and TH17 differentiation by the hypoxia-regulated microRNA miR-210. Nat. Immunol. 2014, 15, 393-401. [CrossRef] [PubMed]

21. Cheng, Q.; Cao, H.; Chen, Z.; Ma, Z.; Wan, X.; Peng, R.; Jiang, B. PAX6, a novel target of miR-335, inhibits cell proliferation and invasion in glioma cells. Mol. Med. Rep. 2014, 10, 399-404. [CrossRef] [PubMed]

22. Hafez, M.M.; Hassan, Z.K.; Zekri, A.R.; Gaber, A.A.; Al Rejaie, S.S.; Sayed-Ahmed, M.M.; Al Shabanah, O. MicroRNAs and metastasis-related gene expression in Egyptian breast cancer patients. Asian Pac. J. Cancer Prev. 2012, 13, 591-598. [CrossRef]

23. Ramadan, A.; Hashim, M.; Hassan, N.M.; Swellam, M. Expression of MiR-335 and its target metalloproteinase genes: Clinical significance in breast cancer. Arch. Physiol. Biochem. 2020, 1-7. [CrossRef] [PubMed]

24. Brennecke, J.; Stark, A.; Russell, R.B.; Cohen, S.M. Principles of microRNA-target recognition. PLoS Biol. 2005, 3, e85. [CrossRef] [PubMed]

25. Guo, N.L.; Zhang, J.X.; Wu, J.P.; Xu, Y.H. Isoflurane promotes glucose metabolism through up-regulation of miR-21 and suppresses mitochondrial oxidative phosphorylation in ovarian cancer cells. Biosci. Rep. 2017, 37. [CrossRef] [PubMed]

26. Zhang, S.; Zhang, J.Y.; Lu, L.J.; Wang, C.H.; Wang, L.H. MiR-630 promotes epithelial ovarian cancer proliferation and invasion via targeting KLF6. Eur. Rev. Med. Pharmacol. Sci. 2017, 21, 4542-4547. [PubMed]

27. Han, X.; Zhang, Y.; Wang, D.; Fu, X.; Li, M.; Wang, A. Upregulation of microRNA-18b induces phosphatase and tensin homolog to accelerate the migration and invasion abilities of ovarian cancer. Oncol. Lett. 2017, 14, 5631-5637. [CrossRef] [PubMed]

28. Corney, D.C.; Hwang, C.I.; Matoso, A.; Vogt, M.; Flesken-Nikitin, A.; Godwin, A.K.; Kamat, A.A.; Sood, A.K.; Ellenson, L.H.; Hermeking, H.; et al. Frequent downregulation of miR-34 family in human ovarian cancers. Clin. Cancer Res. 2010, 16, 1119-1128. [CrossRef]

29. Fan, L.; Wu, Y.; Wang, J.; He, J.; Han, X. Sevoflurane inhibits the migration and invasion of colorectal cancer cells through regulating ERK/MMP-9 pathway by up-regulating miR-203. Eur. J. Pharmacol. 2019, 850, 43-52. [CrossRef]

30. Ren, J.; Wang, X.; Wei, G.; Meng, Y. Exposure to desflurane anesthesia confers colorectal cancer cells metastatic capacity through deregulation of miR-34a/LOXL3. Eur. J. Cancer Prev. 2021, 30, 143-153. [CrossRef]

31. Zhang, H.; Zhang, H.; Zhao, M.; Lv, Z.; Zhang, X.; Qin, X.; Wang, H.; Wang, S.; Su, J.; Lv, X.; et al. MiR-138 inhibits tumor growth through repression of EZH2 in non-small cell lung cancer. Cell Physiol. Biochem. 2013, 31, 56-65. [CrossRef] [PubMed]

32. Jin, Y.; Chen, D.; Cabay, R.J.; Wang, A.; Crowe, D.L.; Zhou, X. Role of microRNA-138 as a potential tumor suppressor in head and neck squamous cell carcinoma. Int. Rev. Cell Mol. Biol. 2013, 303, 357-385.

33. Liu, X.; Wang, C.; Chen, Z.; Jin, Y.; Wang, Y.; Kolokythas, A.; Dai, Y.; Zhou, X. MicroRNA-138 suppresses epithelial-mesenchymal transition in squamous cell carcinoma cell lines. Biochem. J. 2011, 440, 23-31. [CrossRef]

34. Wang, W.; Zhao, L.J.; Tan, Y.X.; Ren, H.; Qi, Z.T. MiR-138 induces cell cycle arrest by targeting cyclin D3 in hepatocellular carcinoma. Carcinogenesis 2012, 33, 1113-1120. [CrossRef] [PubMed]

35. Qiu, S.; Huang, D.; Yin, D.; Li, F.; Li, X.; Kung, H.F.; Peng, Y. Suppression of tumorigenicity by microRNA-138 through inhibition of EZH2-CDK4/6-pRb-E2F1 signal loop in glioblastoma multiforme. Biochim. Biophys. Acta 2013, 1832, 1697-1707. [CrossRef]

36. Yuan, M.; Zhao, S.; Chen, R.; Wang, G.; Bie, Y.; Wu, Q.; Cheng, J. MicroRNA-138 inhibits tumor growth and enhances chemosensitivity in human cervical cancer by targeting H2AX. Exp. Ther. Med. 2020, 19, 630-638. [CrossRef]

37. Yeh, Y.M.; Chuang, C.M.; Chao, K.C.; Wang, L.H. MicroRNA-138 suppresses ovarian cancer cell invasion and metastasis by targeting SOX4 and HIF-1alpha. Int. J. Cancer 2013, 133, 867-878. [CrossRef]

38. Chen, Y.; Cao, K.E.; Wang, S.; Chen, J.; He, B.; He, G.U.; Chen, Y.; Peng, B.; Zhou, J. MicroRNA-138 suppresses proliferation, invasion and glycolysis in malignant melanoma cells by targeting HIF-1alpha. Exp. Ther. Med. 2016, 11, 2513-2518. [CrossRef] [PubMed]

39. Qin, Q.; Furong, W.; Baosheng, L. Multiple functions of hypoxia-regulated miR-210 in cancer. J. Exp. Clin. Cancer Res. 2014, 33, 50. [CrossRef]

40. Zuo, J.; Wen, M.; Lei, M.; Peng, X.; Yang, X.; Liu, Z. MiR-210 links hypoxia with cell proliferation regulation in human Laryngocarcinoma cancer. J. Cell Biochem. 2015, 116, 1039-1049. [CrossRef]

41. Huang, X.; Ding, L.; Bennewith, K.L.; Tong, R.T.; Welford, S.M.; Ang, K.K.; Story, M.; Le, Q.T.; Giaccia, A.J. Hypoxia-inducible mir-210 regulates normoxic gene expression involved in tumor initiation. Mol. Cell 2009, 35, 856-867. [CrossRef]

42. Tsuchiya, S.; Fujiwara, T.; Sato, F.; Shimada, Y.; Tanaka, E.; Sakai, Y.; Shimizu, K.; Tsujimoto, G. MicroRNA-210 regulates cancer cell proliferation through targeting fibroblast growth factor receptor-like 1 (FGFRL1). J. Biol. Chem. 2011, 286, 420-428. [CrossRef]

43. Biswas, S.; Roy, S.; Banerjee, J.; Hussain, S.R.; Khanna, S.; Meenakshisundaram, G.; Kuppusamy, P.; Friedman, A.; Sen, C.K. Hypoxia inducible microRNA 210 attenuates keratinocyte proliferation and impairs closure in a murine model of ischemic wounds. Proc. Natl. Acad. Sci. USA 2010, 107, 6976-6981. [CrossRef]

44. Luo, X.; Zhao, H.; Hennah, L.; Ning, J.; Liu, J.; Tu, H.; Ma, D. Impact of isoflurane on malignant capability of ovarian cancer in vitro. Br. J. Anaesth. 2015, 114, 831-839. [CrossRef] [PubMed]

45. Elias, K.M.; Kang, S.; Liu, X.; Horowitz, N.S.; Berkowitz, R.S.; Frendl, G. Anesthetic selection and disease-free survival following optimal primary cytoreductive surgery for stage III epithelial ovarian cancer. Ann. Surg Oncol 2015, 22, 1341-1348. [CrossRef] [PubMed] 
46. Chen, C.; Liu, R.; Wang, J.; Yan, Z.; Qian, S.; Zhang, W. RNAi Knockdown of Hypoxia-Inducible Factor-1alpha Decreased the Proliferation, Migration, and Invasion of Hypoxic Hepatocellular Carcinoma Cells. Cell Biochem. Biophys. 2015, 71, 1677-1684. [CrossRef] [PubMed]

47. Ban, H.S.; Uno, M.; Nakamura, H. Suppression of hypoxia-induced HIF-1alpha accumulation by VEGFR inhibitors: Different profiles of AAL993 versus SU5416 and KRN633. Cancer Lett. 2010, 296, 17-26. [CrossRef] [PubMed]

48. Jiang, B.H.; Jiang, G.; Zheng, J.Z.; Lu, Z.; Hunter, T.; Vogt, P.K. Phosphatidylinositol 3-kinase signaling controls levels of hypoxia-inducible factor 1. Cell Growth Differ. 2001, 12, 363-369. [PubMed]

49. Talks, K.L.; Turley, H.; Gatter, K.C.; Maxwell, P.H.; Pugh, C.W.; Ratcliffe, P.J.; Harris, A.L. The expression and distribution of the hypoxia-inducible factors HIF-1alpha and HIF-2alpha in normal human tissues, cancers, and tumor-associated macrophages. Am. J. Pathol. 2000, 157, 411-421. [CrossRef]

50. Semenza, G.L. Hypoxia-inducible factors: Mediators of cancer progression and targets for cancer therapy. Trends Pharmacol. Sci. 2012, 33, 207-214. [CrossRef] [PubMed]

51. Monti, E.; Gariboldi, M.B. HIF-1 as a target for cancer chemotherapy, chemosensitization and chemoprevention. Curr. Mol. Pharmacol. 2011, 4, 62-77. [CrossRef] [PubMed]

52. Domcke, S.; Sinha, R.; Levine, D.A.; Sander, C.; Schultz, N. Evaluating cell lines as tumour models by comparison of genomic profiles. Nat. Commun 2013, 4, 2126. [CrossRef] [PubMed]

53. Beaufort, C.M.; Helmijr, J.C.; Piskorz, A.M.; Hoogstraat, M.; Ruigrok-Ritstier, K.; Besselink, N.; Murtaza, M.; van, I.W.F.; Heine, A.A.; Smid, M.; et al. Ovarian cancer cell line panel (OCCP): Clinical importance of in vitro morphological subtypes. PLoS ONE 2014, 9, e103988. [CrossRef] [PubMed] 